Article

\title{
Dihydroisocoumarins from the Mangrove-Derived Fungus Penicillium citrinum
}

\author{
Guo-Lei Huang ${ }^{\dagger},{ }^{\prime}$ Xue-Ming Zhou ${ }^{\dagger}$, Meng Bai, Yu-Xin Liu, Yan-Lei Zhao, You-Ping Luo, \\ Yan-Yan Niu, Cai-Juan Zheng * and Guang-Ying Chen *
}

Key Laboratory of Tropical Medicinal Plant Chemistry of Ministry of Education, College of Chemistry and Chemical Engineering, Hainan Normal University, Haikou 571158, Hainan, China; huangguolei1982@hainnu.edu.cn (G.-L.H.); xueming2009211@126.com (X.-M.Z.); xxbai2014@163.com (M.B.); 18174202788@163.com (Y.-X.L.); 18689506770@163.com (Y.-L.Z.); luoyouping@gmail.com (Y.-P.L.); niuyanyan1986@126.com (Y.-Y.N.)

* Correspondence: caijuan2002@163.com (C.-J.Z.); chgying123@163.com (G.-Y.C.); Tel./Fax: +86-898-6588-9422 (C.-J.Z.)

+ These authors contributed equally to this work.

Academic Editor: Russell Kerr

Received: 3 August 2016; Accepted: 28 September 2016; Published: 10 October 2016

\begin{abstract}
Three new dihydroisocoumarin penicimarins G-I (1-3), together with one known dihydroisocoumarin (4) and three known meroterpenoids (5-7), were obtained from a fungus Penicillium citrinum isolated from the mangrove Bruguiera sexangula var. rhynchopetala collected in the South China Sea. Their structures were elucidated by the detailed analysis of spectroscopic data. The absolute configuration of $\mathbf{1}$ was determined by the $\mathrm{X}$-ray diffraction analysis using $\mathrm{Cu} \mathrm{K} \alpha$ radiation. The absolute configurations of $\mathbf{2}$ and $\mathbf{3}$ were determined by comparison of their circular dichroism (CD) spectra with the literature. All compounds were evaluated for their antibacterial activities and cytotoxic activities.
\end{abstract}

Keywords: Penicillium citrinum; metabolites; dihydroisocoumarin; antibacterial activity; cytotoxic activity

\section{Introduction}

Marine-derived fungi have attracted increasing attention from those seeking new pharmaceutically useful natural products in recent years [1]. In particular, secondary metabolites isolated from the marine-derived fungi in the genus Penicillium can produce various bioactive metabolites, such as antifouling polyketides [2], antibacterial communal A [3], cytotoxic penicinoline [4], antioxidant terrestrols [5], and antileukemic sorbicillactone A [6]. These results have drawn the attention of both pharmaceutical and natural product chemists. In our search for new bioactive natural products from marine fungi in the South China Sea, we have found several bioactive compounds, including anthraquinone derivatives, cytochalasins, lumazine peptides, benzopyrans, stemphol sulfates, triterpenes, and $\alpha$-pyrone derivatives [7-13]. Our previous investigation on the endophytic fungus Penicillium citrinum has resulted in the discovery of one new benzopyran derivative $\left(2 R^{*}, 4 R^{*}\right)-3,4$-dihydro-5-methoxy-2-methyl-2H-1-benzopyran-4-ol [10]. Further, chemical investigation of the fermentation broth of the Penicillium citrinum resulted in the isolation of three new dihydroisocoumarin penicimarins (G-I (1-3)), together with one known dihydroisocoumarin (aspergillumarin A (4)) [14], and three known meroterpenoids (dehydroaustin (5) [15], 11ß-acetoxyisoaustinone (6) [15], and austinol (7) [16]) (Figure 1). All isolated metabolites (1-7) were evaluated for their antibacterial and cytotoxic activities. Herein we report the isolation, structure elucidation, and biological activities of these compounds. 
<smiles>COC(=O)CCC1Cc2ccc(OC)c(O)c2C1</smiles>

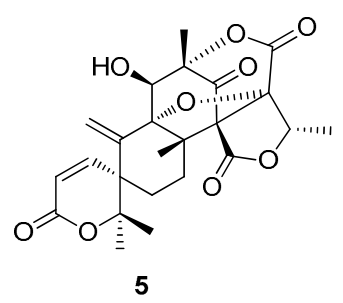

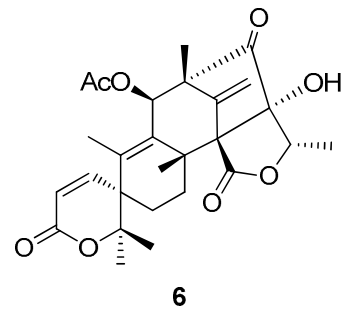

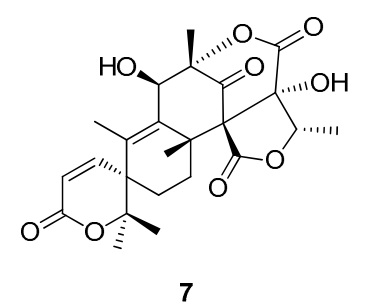

Figure 1. Structures of compounds 1-7.

\section{Results and Discussion}

Compound 1 was obtained as colorless crystals. Its molecular formula of $\mathrm{C}_{15} \mathrm{H}_{20} \mathrm{O}_{5}$ (six degrees of unsaturation) was determined by HR-ESI-MS and combined with ${ }^{1} \mathrm{H}$ and ${ }^{13} \mathrm{C}$ NMR spectroscopic data. In the ${ }^{1} \mathrm{H}$ NMR spectrum (Table 1), the signals and the coupling constants at $\delta_{\mathrm{H}} 7.05(\mathrm{~d}, J=8.4 \mathrm{~Hz}$ ) and $6.90(\mathrm{~d}, J=8.4 \mathrm{~Hz})$ indicated the presence of a 1,2,3,4-tetrasubstituted benzene system. Two oxygenated methine proton signals at $\delta_{\mathrm{H}} 4.39(\mathrm{~m})$ and $3.75(\mathrm{~m})$, one methoxyl group at $\delta_{\mathrm{H}} 3.82(\mathrm{~s})$, one methyl group at $\delta_{\mathrm{H}} 1.17(\mathrm{~d}, J=6.2 \mathrm{~Hz})$, and four methylene groups at $\delta_{\mathrm{H}}(3.16(\mathrm{dd}, J=16.8,3.0 \mathrm{~Hz})$ and $2.58(\mathrm{dd}$, $J=16.8,11.6 \mathrm{~Hz})),(1.84(\mathrm{~m})$ and $1.70(\mathrm{~m})), 1.59(\mathrm{~m})$ and $1.55(\mathrm{~m})$ were also observed. The ${ }^{1} \mathrm{H}$ NMR and ${ }^{13} \mathrm{C}$ NMR spectra indicated that this compound included four methylenes, two methines, one methoxy, and one methyl. The ${ }^{13} \mathrm{C}$ NMR spectrum revealed the signals for six aromatic carbons and one carbonyl carbon, including one lactone carbonyl carbon at $\delta_{C} 165.8$. Thus, these spectroscopic features suggested that 1 was very similar to penicimarin $B$ [17]. The obvious difference in the ${ }^{1} \mathrm{H}$ NMR spectrum was the absence of one aromatic proton signal at $\delta_{\mathrm{H}} 6.79(\mathrm{~d}, J=7.2 \mathrm{~Hz}, \mathrm{H}-5)$ in 1 . Furthermore, in the ${ }^{13} \mathrm{C}$ NMR spectra, the C-5 signal moved downfield significantly $\left[\delta_{C} 148.2(\mathrm{C})\right.$ in $\mathbf{1}$ vs $\left.119.3(\mathrm{CH})\right]$ in penicimarin $\mathrm{B}$, indicating an aromatic proton is replaced by a hydroxyl group. The ${ }^{1} \mathrm{H},{ }^{1} \mathrm{H}-\mathrm{COSY}, \mathrm{HMQC}$, and HMBC spectra allowed the complete assignment for 1 (Figure 2). The relative configuration of 1 could, however, not be confirmed unambiguously. Crystallization of $\mathbf{1}$ from $\mathrm{MeOH}$ afforded colorless crystals, which gave an X-ray crystal structure with a Flack parameter of 0.0 (3) (Figure 3). The absolute configuration of C-3 was also determined by circular dichroism (CD) spectroscopy (Figure 4). The negative circular dichroism at $259 \mathrm{~nm}$ (Figure 4) suggested the $R$ configuration at C-3, by comparison with data for dihydroisocoumarins described in the literature [18]. Thus, compound 1 was named as penicimarin $G$, and the absolute configuration of $\mathbf{1}$ was defined as $\left(3 R, 4^{\prime} R\right)$.

Table 1. NMR spectroscopic data (400/100 MHz) for Compounds 1-3.

\begin{tabular}{|c|c|c|c|c|c|c|}
\hline \multirow{2}{*}{ Position } & \multicolumn{2}{|r|}{$1^{a}$} & \multicolumn{2}{|r|}{$2^{a}$} & \multicolumn{2}{|r|}{$3^{b}$} \\
\hline & $\delta_{C}$, Type & $\delta_{\mathrm{H}}(J$ in $\mathrm{Hz})$ & $\delta_{C}$, Type & $\delta_{\mathrm{H}}(J$ in $\mathrm{Hz})$ & $\delta_{C}$, Type & $\delta_{\mathrm{H}}(J$ in $\mathrm{Hz})$ \\
\hline 1 & $165.8, \mathrm{C}$ & & 165.7, C & & $169.5, \mathrm{C}$ & \\
\hline 3 & $79.6, \mathrm{CH}$ & $4.39(\mathrm{~m})$ & $79.4, \mathrm{CH}$ & $4.39(\mathrm{~m})$ & $78.4, \mathrm{CH}$ & $4.65(\mathrm{~m})$ \\
\hline 4 & 28.7, $\mathrm{CH}_{2}$ & $\begin{array}{c}3.16(\mathrm{dd}, 16.8,3.0) \\
2.58(\mathrm{dd}, 16.8,11.6)\end{array}$ & 28.6, $\mathrm{CH}_{2}$ & $\begin{array}{c}3.15(\mathrm{dd}, 16.8,3.0) \\
2.59(\mathrm{dd}, 16.8,12.0)\end{array}$ & $32.9, \mathrm{CH}_{2}$ & $2.92(\mathrm{~m})$ \\
\hline 5 & $148.2, \mathrm{C}$ & & $148.2, \mathrm{C}$ & & 118.0, CH & $6.89(\mathrm{~d}, 8.0)$ \\
\hline 6 & $122.3, \mathrm{CH}$ & $7.05(\mathrm{~d}, 8.4)$ & $122.3, \mathrm{CH}$ & $7.05(\mathrm{~d}, 9.0)$ & 136.2, CH & $7.42(\mathrm{dd}, 8.0,7.6)$ \\
\hline 7 & $112.8, \mathrm{CH}$ & $6.90(\mathrm{~d}, 8.4)$ & $112.8, \mathrm{CH}$ & $6.90(\mathrm{~d}, 9.0)$ & 116.3, CH & $6.70(\mathrm{~d}, 7.6)$ \\
\hline 8 & $155.8, \mathrm{C}$ & & $155.8, \mathrm{C}$ & & $162.2, \mathrm{C}$ & \\
\hline 9 & $114.8, \mathrm{C}$ & & $114.7, \mathrm{C}$ & & 139.0, C & \\
\hline 10 & $129.5, \mathrm{C}$ & & $129.4, \mathrm{C}$ & & 108.3, C & \\
\hline $1^{\prime}$ & $35.8, \mathrm{CH}_{2}$ & $1.84(\mathrm{~m}), 1.70(\mathrm{~m})$ & $35.1, \mathrm{CH}_{2}$ & $1.79(\mathrm{~m})$ & $29.8, \mathrm{CH}_{2}$ & $2.13(\mathrm{~m})$ \\
\hline $2^{\prime}$ & $23.5, \mathrm{CH}_{2}$ & $1.59(\mathrm{~m})$ & $20.3, \mathrm{CH}_{2}$ & $1.72(\mathrm{~m})$ & $29.2, \mathrm{CH}_{2}$ & $2.62(\mathrm{dd}, 14.4,7.2)$ \\
\hline
\end{tabular}


Table 1. Cont

\begin{tabular}{|c|c|c|c|c|c|c|}
\hline \multirow{2}{*}{ Position } & \multicolumn{2}{|c|}{$1^{a}$} & \multicolumn{2}{|c|}{$2^{a}$} & \multicolumn{2}{|c|}{$3^{b}$} \\
\hline & $\delta_{C}$, Type & $\delta_{H}(J$ in $\mathrm{Hz})$ & $\delta_{C}$, Type & $\delta_{\mathrm{H}}(J$ in $\mathrm{Hz})$ & $\delta_{C}$, Type & $\delta_{\mathrm{H}}(J$ in $\mathrm{Hz})$ \\
\hline $3^{\prime}$ & $39.8, \mathrm{CH}_{2}$ & $1.55(\mathrm{~m})$ & $43.6, \mathrm{CH}_{2}$ & $2.58(\mathrm{~m})$ & 173.2 & \\
\hline $4^{\prime}$ & $68.3, \mathrm{CH}$ & $3.75(\mathrm{~m})$ & 211.4, CH & & $51.8, \mathrm{CH}_{3}$ & $3.70(\mathrm{~s})$ \\
\hline $5^{\prime}$ & $22.3, \mathrm{CH}_{3}$ & $1.17(\mathrm{~d}, 6.2)$ & $29.8, \mathrm{CH}_{3}$ & $2.15(\mathrm{~s})$ & & \\
\hline 8-OMe & $56.7, \mathrm{CH}_{3}$ & $3.82(\mathrm{~s})$ & $56.7, \mathrm{CH}_{3}$ & $3.81(\mathrm{~s})$ & & \\
\hline $8-\mathrm{OH}$ & & & & & & $10.94(\mathrm{~s})$ \\
\hline
\end{tabular}

${ }^{a}$ Recorded in Methanol- $d_{4} ;{ }^{b}$ Recorded in $\mathrm{CDCl}_{3}$.
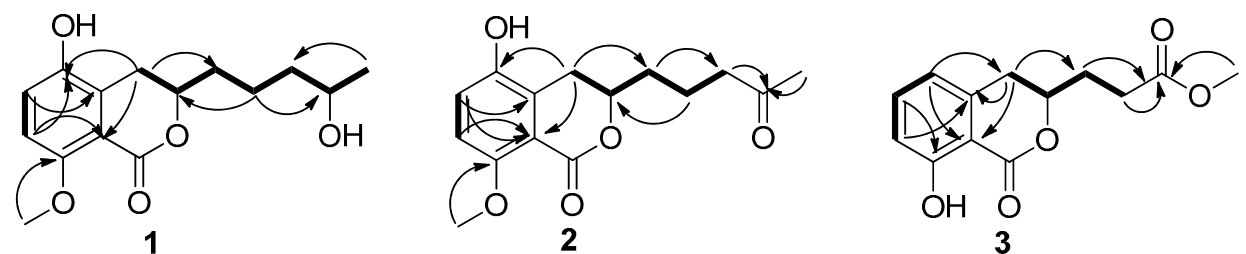

$-{ }^{1} \mathrm{H}_{-}{ }^{1} \mathrm{HCOSY} \bigcirc \mathrm{HMBC}$

Figure 2. ${ }^{1} \mathrm{H}-{ }^{1} \mathrm{H}$ COSY correlations and key HMBC correlations of Compounds 1-3.

$$
{ }^{00}
$$

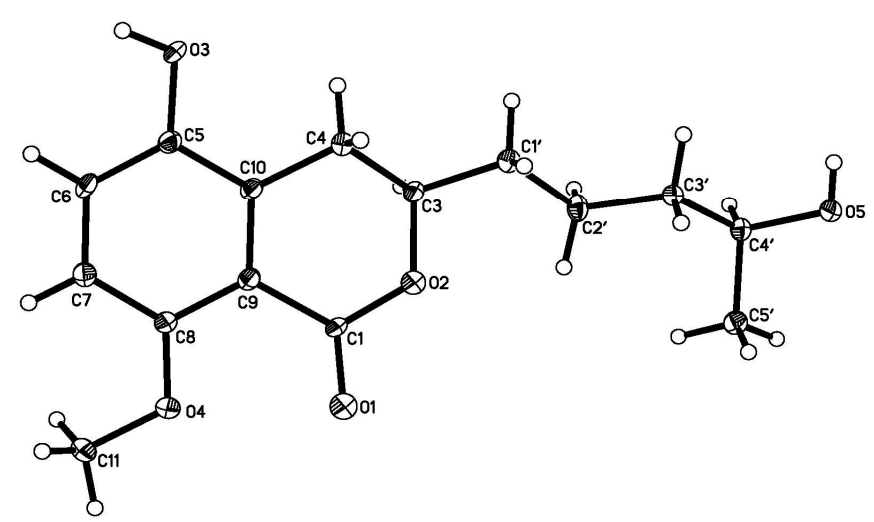

Figure 3. X-ray structure of Compound 1.

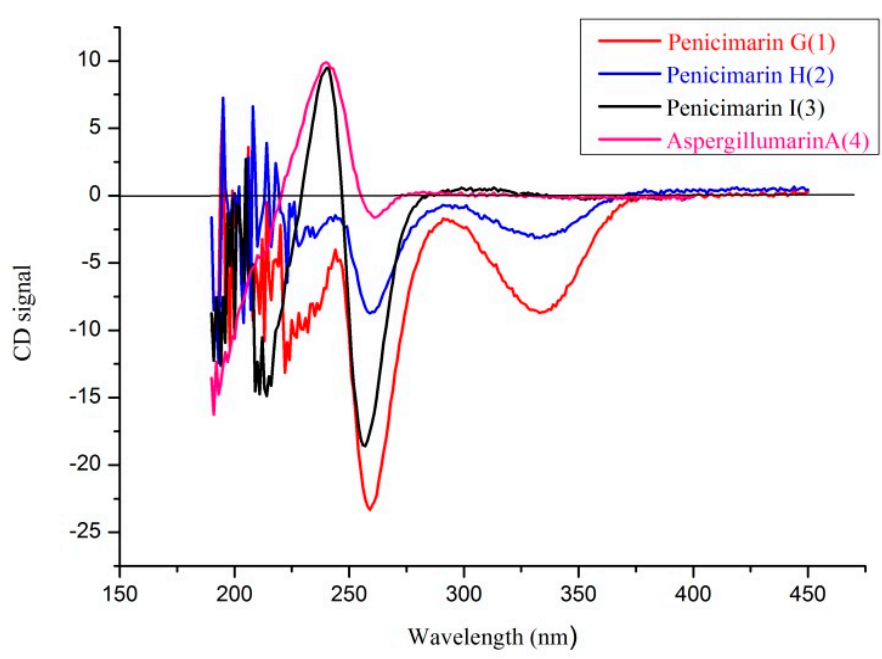

Figure 4. Circular dichroism (CD) spectra of Compounds 1-4. 
Compound 2 was isolated as colorless crystals with the molecular formula assigned as $\mathrm{C}_{15} \mathrm{H}_{18} \mathrm{O}_{5}$ (seven degrees of unsaturation) on the basis of its HR-ESI-MS and combined with ${ }^{1} \mathrm{H}$ and ${ }^{13} \mathrm{C} \mathrm{NMR}$ spectroscopic data. The 1D NMR data of $\mathbf{2}$ was very similar with that of 1, except for the presence of a carbonyl signal $\left(\delta_{C} 211.4\right)$ for $C-4^{\prime}$ in 2 and the absence of one oxygenated methine proton signal $\left(\delta_{\mathrm{C}} 68.3\right)$ for $\mathrm{C}-4^{\prime}$ in 1 . This was corroborated by the HMBC correlations from $\mathrm{H}-3^{\prime}$ and $\mathrm{H}-5^{\prime}$ to $\mathrm{C}-4^{\prime}$ (Figure 2). The ${ }^{1} \mathrm{H}-{ }^{1} \mathrm{H}-\mathrm{COSY}, \mathrm{HMQC}$, and HMBC spectra allowed the complete assignment for 1 . Thus, compound 2 was named as penicimarin $\mathrm{H}$, and the absolute configuration of $\mathrm{C}-3$ was also determined to be $R$ by CD spectra (Figure 4) [18].

Compound 3 was obtained as a colorless oil. Its molecular formula of $\mathrm{C}_{13} \mathrm{H}_{14} \mathrm{O}_{5}$ (seven degrees of unsaturation) was determined by HR-ESI-MS and combined with ${ }^{1} \mathrm{H}$ and ${ }^{13} \mathrm{C}$ NMR spectroscopic data. In the ${ }^{1} \mathrm{H}$ NMR spectrum (Table 1 ), the proton signals and the coupling constants at $\delta_{\mathrm{H}} 7.42(\mathrm{dd}, J=8.0$, $7.6 \mathrm{~Hz}), 6.89(\mathrm{~d}, J=8.0 \mathrm{~Hz})$, and $6.70(\mathrm{~d}, J=7.6 \mathrm{~Hz})$ indicated the presence of an 1,2,3-trisubstituted benzene system. One hydrogen-bonded hydroxyl group at $\delta_{\mathrm{H}} 10.9$ (s), one oxygenated methine proton signal at $\delta_{\mathrm{H}} 4.65(\mathrm{~m})$, one methoxyl group at $\delta_{\mathrm{H}} 3.70(\mathrm{~s})$, and three methylene groups at $\delta_{\mathrm{H}}$ $2.92(\mathrm{~m}), 2.62(\mathrm{~m})$, and $2.13(\mathrm{~m})$ were also observed. The ${ }^{1} \mathrm{H}$ NMR and ${ }^{13} \mathrm{C}$ NMR spectra included three methylenes, one methine, and one methoxy. The ${ }^{13} \mathrm{C}$ NMR data exhibited the presence of six aromatic carbons and two carbonyl carbons, including two lactone carbonyl carbons at $\delta_{C} 173.2$ (C) and 169.7 (C). Thus, these spectroscopic features suggested that 3 was very similar to aspergillumarin A (4) [14]. The obvious differences in the ${ }^{1} \mathrm{H}$ NMR spectra were the absence of one methylene signal at $\delta_{\mathrm{H}} 1.76(\mathrm{~m})$, a singlet methyl signal at $\delta_{\mathrm{H}} 2.16(\mathrm{~s})$, and the presence of a methoxy signal at $\delta_{\mathrm{H}} 3.70$ (s) in 3. The position of this methoxy group was confirmed by the HMBC correlation from $4^{\prime}$-OMe to $\mathrm{C}-3^{\prime}$ (Figure 1). The ${ }^{1} \mathrm{H},{ }^{1} \mathrm{H}-\mathrm{COSY}, \mathrm{HMQC}$, and $\mathrm{HMBC}$ spectra allowed the complete assignment for 3 . Thus, compound $\mathbf{3}$ was named as penicimarin I, and the absolute configuration of C-3 was also determined to be $R$ by CD spectra (Figure 4) [18].

By comparing physical and spectroscopic data with literature values, the four known compounds were identified as aspergillumarin A (4) [14] and three meroterpenoids: dehydroaustin (5) [15], $11 \beta$-acetoxyisoaustinone (6) [15], and austinol (7) [16]. The absolute configuration of C-3 in compound 4 was determined to be $R$ by comparison with the $C D$ spectrum and the optical rotation data of those reported in the literature $[14,18]$.

More detailed spectra of new compounds are available in the Supplementary Materials (Figures S1-S18).

All the isolated compounds were evaluated for their antibacterial activities against five terrestrial pathogenic bacteria and two marine pathogenic bacteria. Compounds 1, 2, and 5-7 exhibited selective antibacterial activity (Table 2). Compounds $\mathbf{2}$ and $\mathbf{7}$ showed moderate activity against Staphylococcus epidermidis and S. aureus with the same minimum inhibitory concentration (MIC) values of $10 \mu \mathrm{M}$. Compounds 1 and $\mathbf{2}$ showed a broad spectrum of antibacterial activity against the five pathogenic bacteria S. epidermidis, S. aureus, Escherichia coli, Bacillus cereus, and Vibrio alginolyticus. All compounds were also tested for cytotoxic activity against HeLa, MCF-7, and A549 cells, however, these compounds showed no cytotoxic activity $\left(\mathrm{IC}_{50}>50 \mu \mathrm{M}\right)$.

Table 2. Antibacterial activity for Compounds 1, 2 and 5-7.

\begin{tabular}{cccccc}
\hline \multirow{2}{*}{ Compound } & \multicolumn{5}{c}{ Minimum Inhibitory Concentration (MIC, $\mu \mathrm{M})$} \\
\cline { 2 - 6 } & S. epidermidis & S. aureus & E. coli & B. cereus & V. alginolyticus \\
\hline $\mathbf{1}$ & 20 & 20 & 20 & 20 & 20 \\
$\mathbf{2}$ & 10 & 20 & $>20$ & 20 & 20 \\
$\mathbf{5}$ & 20 & $>20$ & $>20$ & $>20$ & $>20$ \\
$\mathbf{6}$ & 20 & $>20$ & $>20$ & $>20$ & $>20$ \\
$\mathbf{7}$ & 10 & $>20$ & $>20$ & 20 & $>20$ \\
Ciprofloxacin $^{a}$ & 0.30 & 0.30 & 0.60 & 1.20 & 1.25 \\
\hline \multicolumn{6}{c}{ Ciprofloxacin was used as a positive control. }
\end{tabular}

${ }^{a}$ Ciprofloxacin was used as a positive control. 


\section{Materials and Methods}

\subsection{General Experimental Procedures}

Optical rotations were measured on a JASCO P-1020 digital polarimeter. IR spectra were recorded on a Thermo Nicolet 6700 (using KBr disks) spectrophotometer (Thermo Scientific, Madison, WI, USA). Both 1D and 2D NMR spectra were measured on a Bruker AV-400 (Bruker Corporation, Switzerland) instrument with TMS as the internal standard. HR-ESI-MS spectra were obtained on the Bruker Daltonics Apex-Ultra 7.0 T (Bruker Corporation, Billerica, MA, USA) and the Q-TOF Ultima Global GAA076 LC mass spectrometer. Single-crystal data: Agilent Gemini Ultra X-ray single crystal diffractometer ( $\mathrm{Cu} \mathrm{K} \alpha$ radiation). CD spectra were recorded on a MOS-450 spectrometer. Prep. HPLC were used for Agilent 1260 prep-HPLC system with an Agilent C18 analytical HPLC column $(4.6 \times 250 \mathrm{~mm}, 5 \mu \mathrm{m})$ and semi-preparative column $(9.4 \times 250 \mathrm{~mm}, 7 \mu \mathrm{m})$. Sephadex LH-20 (Pharmacia Co. Ltd, Sandwich, UK) and Silica gel (200-300 mesh, 300-400 mesh Qingdao Marine Chemical Factory, Qingdao, China) were used for column chromatography (CC). All solvents were purchased from Xilong Chemical Reagent Factory (Guangzhou, China).

\subsection{Fungal Materials}

The fungal strain Penicillium citrinum HL-5126 was isolated from the mangrove Bruguiera sexangula var. rhynchopetala collected in the South China Sea in August, 2012. The strain was deposited in the Key Laboratory of Tropical Medicinal Plant Chemistry of Ministry of Education, College of Chemistry and Chemical Engineering, Hainan Normal University, Haikou, China, with the access code HL-5126. The fungal strain was cultivated in $20 \mathrm{~L}$ potato glucose liquid medium $(15 \mathrm{~g}$ of glucose and $30 \mathrm{~g}$ of sea salt in $1 \mathrm{~L}$ of potato infusion, in $1 \mathrm{~L}$ Erlenmeyer flasks each containing $300 \mathrm{~mL}$ of culture broth) at $25^{\circ} \mathrm{C}$ without shaking for 4 weeks.

\subsection{Identification of Fungus}

The fungus was identified according to its morphological characteristics and by comparison of the ITS sequence amplification, primer pair ITS1F and ITS4 and sequencing of the internal transcribed spacer (ITS) region. The sequence data has been submitted to GenBank, with an accession number KJ466981, and the fungal strain was identified as Penicillium citrinum.

\subsection{Extraction and Isolation}

The fungal cultures were filtered through cheesecloth, and the filtrate was extracted with EtOAc $(3 \times 20 \mathrm{~L}, 24 \mathrm{~h}$ each). The organic extracts were concentrated in vacuo to yield an oily residue $(10.2 \mathrm{~g})$, which was subjected to silica gel column chromatography (CC) (petroleum ether, EtOAc v/v, gradient 100:0-0:100) to generate six fractions (Fr. 1-Fr. 5). Fr. 3 was isolated by CC on silica gel eluted with petroleum ether-EtOAc ( $\mathrm{v} / \mathrm{v}$, gradient 100:10-10:100), and then subjected to Sephadex LH-20 CC eluting with mixtures of Petroleum ether: $\mathrm{CHCl}_{3}: \mathrm{MeOH}$ (2:1:1), and further purified by using HPLC on an ODS semi-preparative column (Agilent C18, $9.4 \times 250 \mathrm{~mm}, 7 \mu \mathrm{m}, 2 \mathrm{~mL} / \mathrm{min}$ ) eluted with $80 \% \mathrm{MeOH} / \mathrm{H}_{2} \mathrm{O}$ to obtain compound $1(5.0 \mathrm{mg})$. Fr. 4 was isolated by CC on silica gel eluted with petroleum ether-EtOAc (v/v, gradient 100:10-10:100), and then subjected to Sephadex LH-20 CC eluting with mixtures of $\mathrm{CHCl}_{3}-\mathrm{MeOH}$ (1:1) to obtain Fr. 4.2 (400.0 mg), Fr. 4.3 (106.0 mg). Fr. 4.2 was subjected to repeated Sephadex LH-20 CC $\left(\mathrm{CHCl}_{3} / \mathrm{MeOH}, \mathrm{v} / \mathrm{v}, 1: 1\right)$ and further purified by using HPLC on an ODS semi-preparative column (Agilent C18, $9.4 \times 250 \mathrm{~mm}, 7 \mu \mathrm{m}, 2 \mathrm{~mL} / \mathrm{min}$ ) eluted with $70 \% \mathrm{MeOH} / \mathrm{H}_{2} \mathrm{O}$ to obtain compounds $4(6.0 \mathrm{mg}) 5(8.0 \mathrm{mg}), 6(10.0 \mathrm{mg})$, and 7 (7.0 mg). Fr. 4.3 was subjected to repeated Sephadex LH-20 CC $(\mathrm{MeOH})$ and further purified by using HPLC on an ODS semi-preparative column (Agilent C18, $9.4 \times 250 \mathrm{~mm}, 7 \mu \mathrm{m}, 2 \mathrm{~mL} / \mathrm{min}$ ) eluted with $60 \% \mathrm{MeOH} / \mathrm{H}_{2} \mathrm{O}$ to obtain compounds $2(5.0 \mathrm{mg})$ and $3(6.2 \mathrm{mg})$. 
Penicimarin G (1): Colorless crystals. $[\alpha]_{\mathrm{D}}^{24}-29.0(c=0.25, \mathrm{MeOH}) . \mathrm{mp} 118.8-120.4{ }^{\circ} \mathrm{C} ; \lambda_{\max }(\log \varepsilon)$ 220 (3.02), 246 (2.50), $312(1.62) \mathrm{nm} ; \mathrm{CD}\left(c 2 \times 10^{-4} \mathrm{~mol} / \mathrm{L}, \mathrm{MeOH}\right) \lambda_{\max }(\Delta \varepsilon), 259$ (-23.0), $280(-2.5)$, 330 (-13.6); IR (KBr) $v_{\max } 3518,1712,1602,1272,1250,1230,1112,1082,1064,798 \mathrm{~cm}^{-1} ;{ }^{1} \mathrm{H}$ and ${ }^{13} \mathrm{C}$ NMR see Table 1; HRESIMS $m / z 281.1384$ [M + H] ${ }^{+}$(calcd. for $\mathrm{C}_{15} \mathrm{H}_{21} \mathrm{O}_{5}, 281.1383$ ).

Penicimarin H (2): Colorless crystals. $[\alpha]_{\mathrm{D}}^{24}-24.6(c=0.25, \mathrm{MeOH}) . \mathrm{mp} 136.9-137.6{ }^{\circ} \mathrm{C} . \lambda_{\max }(\log \varepsilon)$ 220 (3.02), 246 (2.50), $312(1.62) \mathrm{nm} ; \mathrm{CD}\left(5.2 \times 10^{-4} \mathrm{~mol} / \mathrm{L}, \mathrm{MeOH}\right) \lambda_{\max }(\Delta \varepsilon) 239$ (+2.00), $257(-8.60)$, 290 (-1.52), 329 (-3.10); IR (KBr) $v_{\max } 3518,1712,1602,1272,1250,1230,1112,1082,1064,798 \mathrm{~cm}^{-1}$; ${ }^{1} \mathrm{H}$ and ${ }^{13} \mathrm{C}$ NMR see Table 1; HRESIMS $m / z$ 579.2200 [2M + Na $]^{+}$(calcd. for $\mathrm{C}_{30} \mathrm{H}_{36} \mathrm{O}_{10} \mathrm{Na}, 579.2200$ ).

Penicimarin I (3): Colorless crystals. $[\alpha]_{\mathrm{D}}^{24}-12.0(c=0.25, \mathrm{MeOH}) . \lambda_{\max }(\log \varepsilon) 220(3.02), 246(2.50)$, $312(1.62) \mathrm{nm} ; \mathrm{CD}\left(4.0 \times 10^{-4} \mathrm{~mol} / \mathrm{L}, \mathrm{MeOH}\right) \lambda_{\max }(\Delta \varepsilon) 240(+9.60), 260(-2.65), 328(-0.16) ; \mathrm{IR}(\mathrm{KBr})$ $v_{\max } 3518,1712,1602,1272,1250,1230,1112,1082,1064,798 \mathrm{~cm}^{-1} ;{ }^{1} \mathrm{H}$ and ${ }^{13} \mathrm{C}$ NMR see Table 1; HRESIMS $m / z 273.0733[\mathrm{M}+\mathrm{Na}]^{+}$(calcd. for $\mathrm{C}_{13} \mathrm{H}_{14} \mathrm{O}_{5} \mathrm{Na}, 273.0740$ ).

X-ray Crystallographic Analysis of $\mathbf{1}$. Colorless crystals of 1 were obtained from $\mathrm{MeOH}$. Single-crystal X-ray diffraction data were collected on a Xcalibur, Atlas, Gemini ultra diffractometer with $\mathrm{Cu} \mathrm{K \alpha}$ radiation $(\lambda=1.54180 \AA)$ at $120.01(10) \mathrm{K}$, respectively. The structure was solved by direct methods (ShelXS) and refined with the ShelXL refinement package using least squares minimization. All non-hydrogen atoms were refined anisotropically, and all hydrogen atoms were placed in idealized positions and refined relatively isotropically with a riding model. Crystallographic data for $\mathbf{1}$ has been deposited in the Cambridge Crystallographic Data Centre with the deposition number CCDC 1489691, respectively. Copies of the data can be obtained, free of charge, on application to the Director, CCDC, 12 Union Road, Cambridge CB21EZ, UK (Fax: +44-(0)1223-336033, or e-mail: deposit@ccdc.cam.ac.uk).

Crystal data for 1: $\mathrm{C}_{15} \mathrm{H}_{22} \mathrm{O}_{6} \cdot \mathrm{H}_{2} \mathrm{O}, M_{\mathrm{r}}=298.33$, orthorhombic, $a=8.1247(2) \AA, b=11.8703(4) \AA$, $c=15.5875(5) \AA, \alpha=90^{\circ}, \beta=90^{\circ}, \gamma=90^{\circ}, V=1503.30(8) \AA^{3}$, space group $P 2{ }_{1} 22_{1}{ }_{1}, Z=4$, $D_{\mathrm{x}}=1.318 \mathrm{mg} / \mathrm{mm}^{3}, \mu(\mathrm{Cu} \mathrm{K} \alpha)=0.848 \mathrm{~mm}^{-1}$, and $F(000)=640$. Independent reflections: 2681 $\left(R_{\text {int }}=0.083\right)$. The final $R_{1}$ values were $0.0389, w R_{2}=0.0979(I>2 \sigma(I))$. Flack parameter $=0.0(3)$.

\subsection{Biological Assays}

Antibacterial activity was determined against five terrestrial pathogenic bacteria, including Staphylococcus epidermidis, S. aureus, Escherichia coli, Pseudomonas aeruginosa and Bacillus cereus, and two marine pathogenic bacteria Vibrio parahaemolyticus and V. alginolyticus by the microtitre plate assay method [19]. Ciprofloxacin was used as the positive control. Cytotoxic activities of all compounds against HeLa, MCF-7 and A549 cell lines were evaluated by the MTT method [20]. Epirubicin was used as a positive control.

\section{Conclusions}

Seven secondary metabolites, including three new dihydroisocoumarin penicimarins G-I (1-3), together with one known dihydroisocoumarin (4) and three known meroterpenoids (5-7), were obtained from a fungus $P$. citrinum isolated from the mangrove B. sexangula var. rhynchopetala collected in the South China Sea. Their structures were elucidated by the detailed analysis of spectroscopic data. The absolute configuration of $\mathbf{1}$ was determined by the X-ray diffraction analysis using $\mathrm{Cu} \mathrm{K} \alpha$ radiation. The absolute configurations of $\mathbf{2}-\mathbf{3}$ were determined by comparison of their CD spectra with literature. All compounds were evaluated for their antibacterial activities and cytotoxic activities.

Supplementary Materials: The following are available online at www.mdpi.com/1660-3397/14/10/177/s1. Figure S1: $1 \mathrm{H}$ NMR $\left(400 \mathrm{MHz}, \mathrm{MeOD}-d_{4}\right)$ spectrum of Compound 1, Figure S2: 13C NMR (100 MHz, MeOD- $\left.d_{4}\right)$ spectrum of Compound 1, Figure S3: HMQC (MeOD- $\left.d_{4}\right)$ spectrum of Compound 1, Figure S4: $1 \mathrm{H}-1 \mathrm{H}$ COSY $\left(\mathrm{MeOD}-d_{4}\right)$ spectrum of Compound 1, Figure S5: HMBC spectrum (MeOD- $d_{4}$ ) of compound 1, Figure S6: HRESIMS spectrum of Compound 1, Figure S7: $\left.1 \mathrm{H} \mathrm{NMR} \mathrm{(400} \mathrm{MHz,} \mathrm{MeOD-} d_{4}\right)$ spectrum of Compound 2, Figure S8: 13C NMR $\left(100 \mathrm{MHz}, \mathrm{MeOD}-d_{4}\right)$ spectrum of Compound 2, Figure S9: HMQC (MeOD- $\left.d_{4}\right)$ spectrum of Compound 2, Figure S10: $1 \mathrm{H}-1 \mathrm{H}$ COSY (MeOD- $\left.d_{4}\right)$ spectrum of Compound 2, Figure S11: HMBC (MeOD- $\left.d_{4}\right)$ spectrum of Compound 2, Figure S12: HRESIMS spectrum of Compound 2, Figure S13: 1H NMR (400 MHz, CDCl3) spectrum 
of Compound 3, Figure S14: 13C NMR (100 MHz, CDCl3) spectrum of Compound 3, Figure S15: HMQC (CDCl3) spectrum of Compound 3, Figure S16: 1H-1H COSY (CDCl3) spectrum of Compound 3, Figure S17: HMBC (CDCl3) spectrum of Compound 3, Figure S18: HRESIMS spectrum of Compound 3.

Acknowledgments: This work was supported by the Foundation for the National Natural Science Foundation of China (No. 21462015), Marine Science and Technology Program of Hainan Province (No. 2015XH06), National Natural Science Foundation of Hainan Province (Nos. 20152034, 20162019 and 20162030), Hainan province natural science foundation of innovatie research team project (No. 2016CXTD007).

Author Contributions: C.-J.Z. and G.-L.H. conceived and designed the experiments; G.-L.H., X.-M.Z., M.B., Y.-X.L., Y.-L.Z., Y.-P.L. and Y.-Y.N. performed the experiments; C.-J.Z., G.-L.H. X.-M.Z., and G.-Y.C. analyzed the data; C.-J.Z. and G.-L.H. wrote the paper. C.-J.Z. designed and contributed the study and reviewed the manuscript.

Conflicts of Interest: The authors declare no conflict of interest.

\section{References}

1. Blunt, J.W.; Copp, B.R.; Keyzers, R.A.; Munro, M.H.G.; Prinsep, M.R. Marine natural products. Nat. Prod. Rep. 2015, 32, 116-211. [CrossRef] [PubMed]

2. Bao, J.; Sun, Y.L.; Zhang, X.Y.; Han, Z.; Gao, H.C.; He, F.; Qian, P.Y.; Qi, S.H. Antifouling and antibacterial polyketides from marine gorgonian coral-associated fungus Penicillium sp. SCSGAF 0023. J. Antibiot. 2013, 66, 219-223. [CrossRef] [PubMed]

3. Wang, J.F.; Liu, P.P.; Wang, Y.; Wang, H.; Li, J.; Zhuang, Y.B.; Zhu, W.M. Antimicrobial aromatic polyketides from gorgonian-associated fungus, Penicillium commune 518. Chin. J. Chem. 2012, 30, 1236-1242. [CrossRef]

4. Shao, C.L.; Wang, C.Y.; Gu, Y.C.; Wei, M.Y.; Pan, J.H.; Deng, D.S.; She, Z.G.; Lin, Y.C. Penicinoline, a new pyrrolyl 4-quinolinone alkaloid with an unprecedented ring system from an endophytic fungus Penicillium sp. Bioorg. Med. Chem. Lett. 2010, 20, 3284-3286. [CrossRef] [PubMed]

5. Chen, L.; Fang, Y.C.; Zhu, T.J.; Gu, Q.Q.; Zhu, W.M. Nine new gentisyl alcohol derivatives from marine-derived fungus Penicillium terrestre. J. Nat. Prod. 2008, 71, 66-70. [CrossRef] [PubMed]

6. Bringmann, G.; Lang, G.; Gulder, T.A.M.; Tsuruta, H.; Muhlbacher, J.; Maksimenka, K.; Steffens, S.; Schaumann, K.; Stohr, R.; Wiese, J.; et al. The first sorbicillinoid alkaloids, the antileukemic sorbicillactones A and B, from a sponge-derived Penicillium chrysogenum strain. Tetrahedron 2005, 61, 7252-7265. [CrossRef]

7. Zhou, X.M.; Zheng, C.J.; Chen, G.Y.; Song, X.P.; Han, C.R.; Li, G.N.; Fu, Y.H.; Chen, W.H.; Niu, Z.G. Bioactive anthraquinone derivatives from the mangrove-derived fungus Stemphylium sp. 33231. J. Nat. Prod. 2014, 77, 2021-2028. [CrossRef] [PubMed]

8. Zheng, C.J.; Shao, C.L.; Wu, L.Y.; Chen, M.; Wang, K.L.; Zhao, D.L.; Sun, X.P.; Chen, G.Y.; Wang, C.Y. Bioactive phenylalanine derivatives and cytochalasins from the soft coral-derived fungus Aspergillus elegans. Mar. Drugs 2013, 11, 2054-2068. [CrossRef] [PubMed]

9. Zheng, C.J.; Wu, L.Y.; Li, X.B.; Song, X.M.; Niu, Z.G.; Song, X.P.; Chen, G.Y.; Wang, C.Y. Structure and absolute configuration of aspergilumamide A, a novel lumazine peptide from the mangrove-derived fungus Aspergillus sp. Helv. Chim. Acta 2015, 98, 368-373. [CrossRef]

10. Zheng, C.J.; Huang, G.L.; Xu, Y.; Song, X.M.; Yao, J.; Liu, H.; Wang, R.P.; Sun, X.P. A new benzopyrans derivatives from a mangrove-derived fungus Penicillium citrinum from the South China Sea. Nat. Prod. Res. 2016, 30, 821-825. [CrossRef] [PubMed]

11. Zhou, X.M.; Zheng, C.J.; Chen, G.Y.; Song, X.P.; Han, C.R.; Tang, X.Z.; Liu, R.J.; Ren, L.L. Two new stemphol sulfates from the mangrove endophytic fungus Stemphylium sp. 33231. J. Antibiot. 2015, 68, 501-503. [CrossRef] [PubMed]

12. Zheng, C.J.; Huang, G.L.; Tang, X.Z.; Wang, D.N.; Gong, X.L.; Zhang, Q.; Song, X.P.; Chen, G.Y. Secondary metabolites and antibacterial activities of a Bruguiera sexangula var. Rhynchopetala-derived fungus Penicillium sp. (J41221). Chin. J. Org. Chem. 2014, 34, 1172-1176. [CrossRef]

13. Zhou, X.M.; Zheng, C.J.; Song, X.P.; Han, C.R.; Chen, W.H.; Chen, G.Y. Antibacterial $\alpha$-pyrone derivatives from a mangrove-derived fungus Stemphylium sp. 33231 from the South China Sea. J. Antibiot. 2014, 67, 401-403. [CrossRef] [PubMed]

14. Li, S.D.; Wei, M.Y.; Chen, G.Y.; Lin, Y.C. Two new dihydroisocoumarins from the endophytic fungus Aspergillus sp. collected from the South China Sea. Chem. Nat. Compd. 2012, 48, 371-373. [CrossRef] 
15. Arunpanichlert, J.; Rukachaisirikul, V.; Phongpaichit, S.; Supaphon, O.; Sakayaroj, J. Meroterpenoid, isocoumarin, and phenol derivatives from the seagrass-derived fungus Pestalotiopsis sp. PSU-ES194. Tetrahedron 2015, 71, 882-888. [CrossRef]

16. Hayashi, H.; Mukaihara, M.; Murao, S.; Arai, M.; Lee, A.Y.; Clardy, J. Acetoxydehydroaustin, a new bioactive compound, and related compound neoaustin from Penicillium sp. MG-11. Biosci. Biotechnol. Biochem. 1994, 58, 334-338. [CrossRef]

17. Qi, J.; Shao, C.L.; Li, Z.Y.; Gan, L.S.; Fu, X.M.; Bian, W.T.; Zhao, Y.X.; Wang, C.Y. Isocoumarin derivatives and benzofurans from a sponge-derived Penicillium sp. fungus. J. Nat. Prod. 2013, 76, 571-579. [CrossRef] [PubMed]

18. Choukchou-Braham, N.; Asakawa, Y.; Lepoittevin, J.P. Isolation, structure determination and synthesis of new dihydroisocoumarins from Ginkgo biloba L. Tetrahedron Lett. 1994, 35, 3949-3952. [CrossRef]

19. Pierce, C.G.; Uppuluri, P.; Teistan, A.R.; Wormley, F.L.J.; Mowat, E.; Ramage, G.; Lopez-ribot, J.L. A simple and reproducible 96-well plate-based method for the formation of fungal biofilms and its application to antifungal susceptibility testing. Nat. Protoc. 2008, 3, 1494-1500. [CrossRef] [PubMed]

20. Scudiero, D.A.; Shoemaker, R.H.; Paull, K.D.; Monks, A.; Tierney, S.; Nofziger, T.H.; Currens, M.J.; Seniff, D.; Boyd, M.R. Evaluation of a soluble tetrazolium/formazan assay for cell growth and drug sensitivity in culture using human and other tumor cell lines. Cancer Res. 1988, 48, 4827-4833. [PubMed]

(C) 2016 by the authors; licensee MDPI, Basel, Switzerland. This article is an open access article distributed under the terms and conditions of the Creative Commons Attribution (CC-BY) license (http:/ / creativecommons.org/licenses/by/4.0/). 